\title{
МЕХАНІЗМИ АДАПТИВНОГО УПРАВЛІННЯ МЕТОДИЧНОЮ РОБОТОЮ ПЕДАГОГІВ ЗАКЛАДІВ ПОЗАШКІЛЬНОЇ ОСВІТИ
}

Нині в освітній системі країни великого значення набуває методична робота як складник освітнього простору закладу освіти. Метою діяльності методичної роботи є надання допомоги педагогічним працівникам у розвитку їх професійної майстерності, активізації творчого потенціалу, оволодінні сучасними технологіями навчання та виховання.

У статті автор акцентує увагу на методичній роботі закладів позашкільної освіти як основного виду освітньої діяльності педагогів. Саме методична діяльність забезпечує безперервний зв'язок із проблемою, над якою працює педагог, результатом чого є організований на належному рівні освітній процес закладу. Це дає змогу протягом певного часу глибоко вивчати діяльність педагогічного колективу.

Підвищення рівня якості надання освітніх послуг у закладі позашкільної освіти залежить від рівня методичної роботи закладу. Важливим моментом у виріменні иієї проблеми є керівництво методичною роботою закладу. Автор висвітлює кониептуальні підходи до управління методичною роботою закладу позашкільної освіти в умовах модернізації освітньої системи в Україні та визначає характеристики структури управління методичною роботою.

У статті акиентується увага на адаптивному стилі керівництва методичною роботою закладу позашкільної освіти як ефективному стилі керівництва, який має низку переваг. Автор доводить, щзо найпродуктивнішим напрямом управління методичною роботою позашкільного навчального закладу є використання системи адаптивного управління. Підвищення адаптивності керівництва відбувається за рахунок перепроектування завдань, переформування творчих груп або модифікації посадових повноважень. Ефективне управління методичною роботою закладу є запорукою успішного функиіонування та адаптації закладу до нових умов. Адаптивний стиль керівництва, в основі якого лежить демократичний стиль, який базується на взаємодії, співробітництві, конструктивному вирішенні проблем, дає найкращі результати в наданні освітніх послуг.

Ключові слова: заклад позашкільної освіти, методична робота, адаптивне управління.

\section{MECHANISMS OF ADAPTIVE MANAGEMENT OF METHODOLOGICAL WORK OF TEACHERS OF EXTRACURRICULAR EDUCATION INSTITUTIONS}

Today in the educational system of the country methodical work as a component of educational space of educational institution acquires great value. The purpose of the methodical work is to assist teachers in the development of their professional skills, activation of creative potential, mastering modern technologies of teaching and education.

In the article the author focuses on the methodical work of out-of-school educational institutions as the main type of educational activity of teachers. It is the methodological activity that provides a continuous connection with the problem that the teacher is working on, the result of which is a well-organized educational process of the institution. Gives the opportunity to deeply, for some time to study the activities of pedagogical experience.

Improving the level of quality of educational services in out-of-school education depends on the level of methodological work of the institution. An important point in solving this problem is the management of the methodological work of the institution. The author highlights the conceptual approaches to the management of methodical work of out-of-school education in the modernization of the educational system in Ukraine and determines the characteristics of the management structure of methodical work. 
The article focuses on the adaptive leadership style of the methodical work of the out-of-school education institution, as an effective leadership style that has a number of advantages. The author proves that the most productive direction of management of methodical work of out-of-school educational institution is use of system of adaptive management. Increasing the adaptability of management is due to the redesign of tasks, reformulation of creative groups or modification of job responsibilities. Effective management of the methodical work of the institution is the key to successful operation and adaptation of the institution to new conditions. Adaptive leadership style, which is based on a democratic style based on interaction, cooperation, constructive problem solving, gives the most important results in the provision of educational services.

Key words: out-of-school education institution, methodical work, adaptive management.

Постановка проблеми. Сучасні тенденції гуманізації життя зумовлюють зміни в управлінні соціальними процесами. Реалізація концепції стратегічного управління позашкільним навчальним закладом можлива тоді, коли керівник і педагогічний колектив цього закладу розуміють $\mathrm{i}$ виражають готовність до якісного оновлення своєї діяльності. Проблеми пошуку ефективних способів формування моделі управління структурними елементами закладу позашкільної освіти є надзвичайно актуальними. За сучасних умов розвитку освіти в Україні виняткового значення набуває система методичної роботи, головною метою якої $\epsilon$ не лише надання реальної допомоги педагогічним кадрам у розвитку їхньої професійної майстерності, але й активізація творчого потенціалу кожного вчителя, керівника гуртка, керівника наукової роботи учня.

Аналіз досліджень. Проблеми управління закладом позашкільної освіти досліджували І. Д. Бех, Г. І. Сльнікова, Ю. К. Бабанський, Г. А. Дмитренко, С. С. Березняк та інші.

Мета статті - розкрити суть ефективної організації адаптивного управління методичною роботою закладу позашкільної освіти.

Виклад основного матеріалу. Позашкільні навчальні заклади як осередки реалізації завдань позашкільної освіти здійснюють державну політику в галузі освіти, культури, науки, виробництва і сприяють розвитку творчої особистості, забезпечують визначення стратегічних напрямів розвитку позашкільної освіти відповідно до соціальних, економічних, культурних, дозвіллєвих умов життєдіяльності та життєтворчості суспільства.

Методична робота - це заснована на досягненнях науки та передового досвіду система аналітичної, організаційної, діагностичної, пошукової, дослідницької, науково-практичної, інформаційної діяльності з метою удосконалення професійної компетентності педагогічних працівників і підвищенняефективностінавчально-виховногопроцесу. Заклади позашкільної освіти проводять інформаційно-методичну роботу, спрямовану на вдосконалення програм, змісту, форм і методів діяльності гуртків, груп та інших творчих об'єднань, підвищення майстерності педагогічних працівників за напрямами роботи (Книга методиста, 2006).

Правові засади методичної роботи закладів позашкільної освіти визначаються Законом України «Про позашкільну освіту», «Положенням про позашкільний навчальний заклад», Концепцією позашкільної освіти та виховання. Відповідно до Положення про позашкільний навчальний заклад заклад позашкільної освіти проводить освітню діяльність, спрямовану на навчально-виховну, навчально-тренувальну, інформаційно-методичну та організаційно-масову роботу.

Інформаційно-методична робота спрямована на удосконалення програм, змісту, форм, методів діяльності гуртків, секцій, клубів та інших творчих об'єднань дітей та учнівської молоді. Ця робота здійснюється відповідно до Статуту конкретного закладу та Програми його подальшого розвитку і спрямована на удосконалення навчальновиховної, організаційно-масової, інструктивнометодичної діяльності в самому закладі. Крім того, відповідно до замовлень управлінь, відділів освіти, культури, молоді і спорту місцевих органів виконавчої влади позашкільні навчальні заклади можуть поширювати свою організаційнометодичну діяльність на заклади, які віднесені до структурних складників позашкільної освіти.

Структура управління методичною роботою базовими повинна мати такі характеристики: адаптивність; інтегрованість і комплексність; чітке ціннісне спрямування. Одним із продуктивних напрямів цієї роботи є використання системи адаптивного управління (Королюк, 2007). Адаптивне керівництво, за визначенням Г. В. Сльникової,--цездатність керівника вибирати і об'єднувати різні стилі управління залежно від ситуації. При цьому підвищення адаптивності керівництва досягається за рахунок перепроектування завдань, переформування творчих груп або модифікації посадових повноважень (Єльникова, 2003).

Адаптивне управління має свої закономірності, якідаютьзмогувиокремитипринципи адаптивного управління: принцип пріоритетного визнання розвитку людини (організації) і визначальності природного шляху його здійснення, управління через 
самоуправління, принцип резонансу, наскрізнорівневої адаптації і діалогічної узгодженості, мотивації, постійного підвищення компетентності, спрямованої самоорганізації, кооперації, поточного саморегулювання, спільного прогнозування подальшого розвитку за аналізом результату (Сльникова, 2004). Можна зазначити, що адаптивний стиль керівництва - це гнучкий, оптимальний, орієнтований на реальність стиль, який $\epsilon$ дієвим у конкретній ситуації, за конкретних умов.

Характерними ознаками адаптивного стилю керівництва $є$ :

1) урахування реальних потреб і вимог до керівництва;

2) пристосування до конкретної ситуації, конкретних умов праці;

3) гнучке застосування різних методів, засобів, прийомів, відомих класифікацій стилів;

4) урахування рівня розвитку структури;

5) врахування індивідуальних особливостей підлеглих.

Застосування адаптивного стилю керівництва може забезпечити ефективність управління, сприятиме розвитку закладу, колективу, задоволеності власною працею та творчому зростанню кожної його особистості.

Для формування адаптивного стилю керівництва важливим $€$ :

1) умотивованість керівників щодо покращення власного стилю керівництва;

2) усвідомлення власного стилю, виявлення його позитивних і негативних сторін;

3) корекція недоліків, постійна робота 3 удосконалення (Ратькова, 2009).

Керівникам пропонується забезпечити такі умови, необхідні для формування адаптивного стилю керівництва:

- здійснення індивідуального підходу до кожного підлеглого;

- урахування рівня розвитку закладу;

- урахування рівня розвитку педагогічного колективу;

- залучення підлеглих до управління;

- делегування повноважень;

- інформування підлеглих;

- забезпечення гласності у колективі;

- скасування командно-адміністративних методів керівництва;

- створення атмосфери співпраці у колективі; ації;

- урахування місцевих умов, конкретної ситу-

- виявлення поваги та довіри до підлеглих;

- забезпечення оптимістичного настрою

у колективі;
- забезпечення партнерських стосунків;

- створення умов для реалізації творчої особистості кожного підлеглого.

Керівник має пам'ятати, що основним його імперативом $\epsilon$ розуміння власної відповідальності перед людьми, прагнення забезпечити їх задоволеність працею, реалізація творчого потенціалу з використанням можливостей закладу та власних. 3 метою ефективного управління керівник має:

- усвідомити позитивні і негативні риси власного стилю керівництва;

- навчитися користуватися всіма відомими методами, прийомами та засобами управлінської діяльності;

- реагувати на ситуацію гнучко;

- використовувати адаптивний стиль, орієнтований на реальність.

Основніпринципиметодичної роботи:демократизація та гуманізація навчального процесу, системність і систематичність, науковість, оперативність та мобільність, прогностичність, оптимальне поєднання індивідуальних і колективних форм.

Основними завданнями методичної роботи $\epsilon$ :

- організаційно-методичне забезпечення програм розвитку;

- удосконалення змісту, форм i методів навчання та виховання учнівської молоді, забезпечення єдності органічного зв'язку школи та позашкільного навчального закладу;

- організаційно-методична допомога у розвитку педагогічної творчості, експериментальнодослідницькій роботі, впровадженні результатів наукових досліджень, передового досвіду, педагогічних технологій;

- створення комплексно-методичного забезпечення предметів, розробка та видання навчальних, методичних посібників, рекомендацій (рис. 1) (Методичний посібник для педколективів позашкільних закладів, 2000).

У позашкільних навчальних закладах здійснюється колективна та індивідуальна методична робота. Основою у виборі форм методичної роботи $€$ різні методи діагностичного вивчення рівня професійної компетентності педагогічних працівників.

Колективні форми методичної роботи використовуються 3 метою вироблення єдиного підходу до вирішення певних проблем, обговорення актуальних питань організації навчально-виховного процесу, аналізу результатів колективної діяльності, вивчення і поширення кращого педагогічного досвіду, пошуково-технічної та педагогічної інформації. Колективними формами методичної роботи є методичні комісії, інструктивно-методичні наради, теоретичні та практичні семінари, 
Ворона А. Механізми адаптивного управління методичною роботою ...

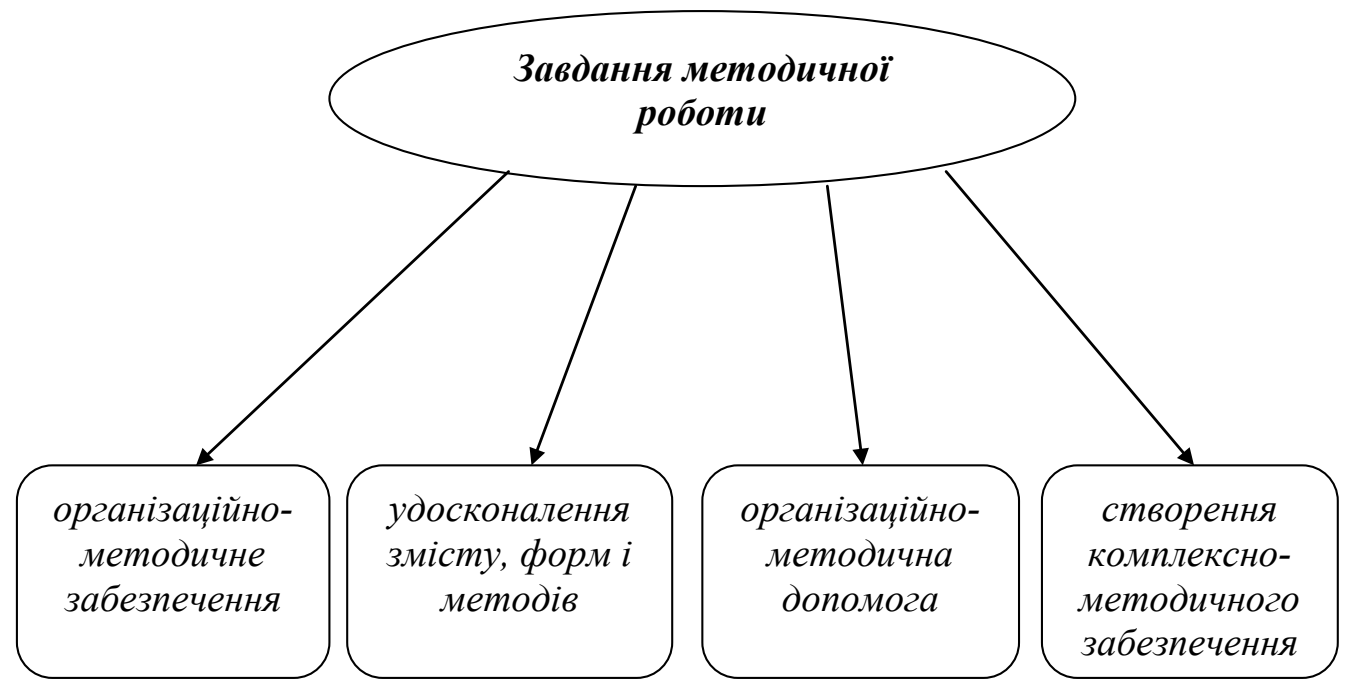

Рис. 1. Основні завдання методичної роботи

школи професійної майстерності, передового досвіду, науково-практичні конференції (рис. 2) (Ратькова, 2009).

Інструктивно-методичні наради проводить керівник територіального відділення 3 метою інформування відповідальних по роботі з обдарованою молоддю, оперативного вивчення та обговорення нормативних актів, документів, окремих поточних питань щодо організації роботи. Проблемні семінари, семінари-практикуми, лекторії, школи передового досвіду організовуються 3 метою поглибленого вивчення найважливіших питань навчально-виховного процесу, пропаганди та впровадження конкретного передового досвіду i проводяться диференційовано залежно від поставлених завдань, складу педагогічних працівників, рівня їхньої професійної компетентності. На науково-практичних конференціях і педагогічних читаннях обговорюються актуальні педагогічні проблеми, система роботи кращих навчальних закладів, педагогічних працівників, заслуховуються доповіді та інші матеріали 3 окремих педагогічних теорій і практики, підбиваються підсумки.

Система управління включає складання плану, вироблення і прийняття управлінського рішення, регулювання, забезпечення обліку й контролю. Ці складники системи управління поширюються на всі сфери діяльності суспільства, в тому числі й на організацію роботи закладів освіти, а саме на управління методичною роботою навчального закладу (Методичні рекомендації, 2007). Під час організації методичної роботи та їі планування враховуються актуальні завдання розвитку сучасної освіти, програмні цілі навчальних закладів.
Планування методичної роботи - це система заходів, яка забезпечує іiї безперервність, впорядкованість, визначеність, відповідність потребам навчально-виховного процесу та особистим запитам педагогічних працівників. Планування методичної роботи здійснюється до початку нового навчального року. Під час планування враховуються недоліки методичної роботи, які були допущені в минулому році, та побажання методистів щодо покращення роботи. Вкінці навчального року проводиться обговорення результатів виконаної методичної роботи (Павлютенко, 2008).

Висновки. Найпродуктивнішим напрямом управління методичною роботою позашкільного навчального закладу $є$ використання системи адаптивного управління. У методичній роботі закладів позашкільної освіти переваги надаються колек-

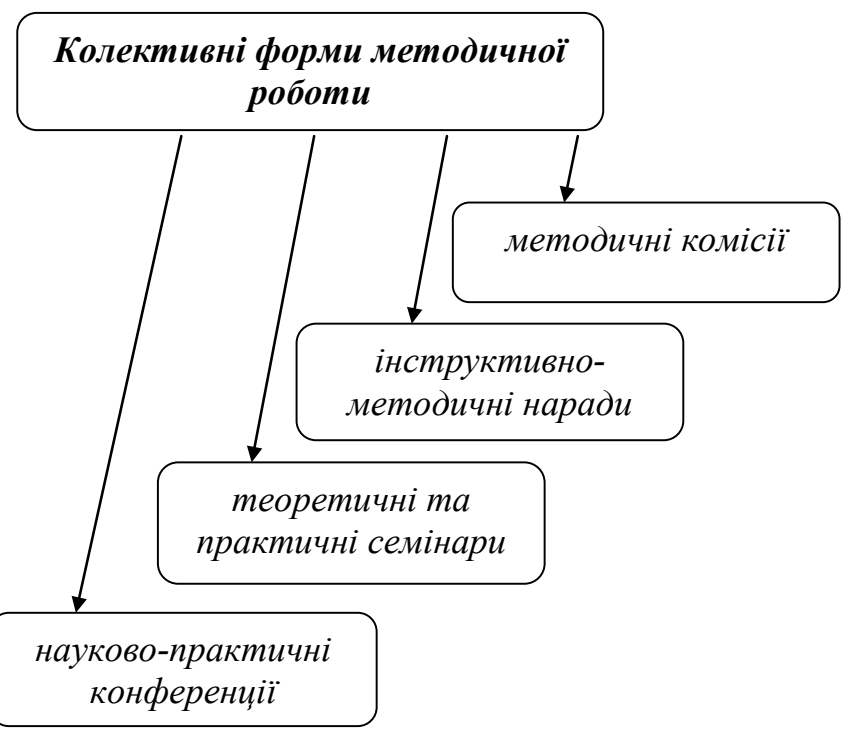

Рис. 2. Основні форми колективної методичної роботи 
тивним формам роботи. Колективні форми методичної роботи спрямовані на успішну діяльність роботи профільних гуртків, наукових товариств учнів ізалучення учнівської молоді до роботи в них.

Підвищення ефективності управління сучасним позашкільним навчальним закладом необхідно починати зі створення або перетворення системи інформаційного забезпечення та форму- вання системи інформаційно-аналітичної діяльності як основного інструменту управління. Ефективна управлінська діяльність є запорукою успішної адаптації закладу до нових соціальноекономічних умов. Демократичний стиль керівництва, який базується на взаємодії, співробітництві, конструктивному вирішенні проблем, дає найкращі результати.

\section{СПИСОК ВИКОРИСТАНИХ ДЖЕРЕЛ}

1. Сльникова Г. В. Витоки адаптивного управління організаціями, в тому числі загальної середньої освіти / Післядипломна освіта в Україні, 2003, № 3, С. 78-81.

2. Сльникова Г. В. Підготовка керівників шкіл до адаптивного управління / Підготовка керівника середнього закладу освіти : навчальний посібник / За ред. Л. І. Даниленко. К. : Міленіум, 2004. С. 133-141.

3. Книга методиста. Харків : Торсінг плюс, 2006.

4. Організаційно-педагогічні основи діяльності сучасного позашкільного навчального закладу. Методичний посібник для педколективів позашкільних закладів. Частина 1. К. : МОН, 2000.

5. Павлютенко Є. М., Крижко В. В. Організація методичної роботи. Х. : Основа, 2008, 80 с.

6. Ратькова А. Новий погляд на структуру методичної роботи / Директор школи. 2009, №№ 9-10. С. 5-9.

7. Система управління позашкільним навчальним закладом: методичні рекомендації. Івано-Франківськ, 2007.

\section{REFERENCES}

1. Yelnykova H. V. Vytoky adaptyvnoho upravlinnya orhanizatsiyamy, $v$ tomu chysli zahalnoyi serednoyi osvity [Yelnikova G. V. Origins of adaptive management of organizations, including - general secondary education] / Pislyadyplomna osvita v Ukrayini, 2003, № 3. S. 78-81 [in Ukrainian].

2. Yelnykova H. V. Pidhotovka kerivnykiv shkil do adaptyvnoho upravlinnya [Yelnikova G. V Preparation of school principals for adaptive management] / Pidhotovka kerivnyka serednoho zakladu osvity : navchalnyy posibnyk / Za red. L. I. Danylenko. K. : Milenium, 2004. S. 133-141 [in Ukrainian].

3. Knyha metodysta. [Book Methodist]. Kharkiv : Torsinh plyus, 2006 [in Ukrainian].

4. Orhanizatsiyno-pedahohichni osnovy diyalnosti suchasnoho pozashkilnoho navchalnoho zakladu. [Organizational and pedagogical bases of modern out-of-school educational institution]. Metodychnyy posibnyk dlya pedkolektyviv pozashkilnykh zakladiv. Chastyna 1. K. : MON, 2000] [in Ukrainian].

5. Pavlyutenko YE. M., Kryzhko V. V. [Pavlyutenko E. M., Kryzhko V. V. Organization of methodical work]. Orhanizatsiya metodychnoyi roboty. KH. : Osnova, 2008. 80 s. [in Ukrainian].

6. Ratkova A. Novyy pohlyad na strukturu metodychnoyi roboty [Ratkova A. A new look at the structure of methodical work] / Dyrektor shkoly, 2009, №№ 9-10. S. 5-9 [in Ukrainian].

7. Systema upravlinnya pozashkilnym navchalnym zakladom. [Management system of out-of-school educational: metodychni rekomendatsiyi]. Ivano-Frankivsk, 2007 [in Ukrainian]. 